CLIMATE SAVVY 



\section{Climate Savvy}

ADAPTING CONSERVATION AND RESOURCE

MANAGEMENT TO A CHANGING WORLD

Lara J. Hansen and Jennifer R. Hoffman

\section{OisLANDPRESS}

Washington | Covelo | London 
Copyright (C) 2011 Island Press

All rights reserved under International and Pan-American Copyright Conventions. No part of this book may be reproduced in any form or by any means without permission in writing from the publisher:

Island Press, 1718 Connecticut Avenue NW, Suite 300, Washington, DC 20009

Island Press is a trademark of The Center for Resource Economics.

Library of Congress Cataloging-in-Publication Data

Hansen, Lara J.

Climate savvy : adapting conservation and resource management to a changing world / Lara J. Hansen and Jennifer R. Hoffman.

p. $\mathrm{cm}$.

Includes bibliographical references and index.

ISBN-13: 978-1-59726-685-7 (cloth : alk. paper)

ISBN-10: 1-59726-685-X (cloth : alk. paper)

ISBN-13: 978-1-59726-686-4 (pbk. : alk. paper)

ISBN-10: 1-59726-686-8 (pbk. : alk. paper)

1. Conservation of natural resources. 2. Natural resources-Management. 3. Climatic changes.

I. Hoffman, Jennifer R. II. Title.

S936.H36 2010

$304.2 ' 5-\mathrm{dc} 22$

2010035547

Printed on recycled, acid-free paper

Manufactured in the United States of America

10987654321

KEYWORDS: Climate change, adaptation, resource management, resilience, restoration, invasive species, conservation, natural resources, connectivity, climate models, protected areas, changing world, natural resource policy, government agencies, conservation biology, restoration ecology, climate scientists, endangered species, assisted migration, vulnerability assessment. 




\section{CONTENTS}

Chapter 1 In the Beginning 1

Chapter 2 Climate Change and Its Effects: What You Need to Know 6

Chapter 3 Reconceiving Conservation and Resource Management 24

\section{PART I BUILDING THE PLAN}

Chapter 4 Buying Time: The Tao of Adaptation 37

Chapter 5 Assessing Vulnerability to Climate Change $\quad 55$

Chapter 6 Developing Strategies to Reduce Vulnerability 70

$\begin{array}{lll}\text { Chapter } 7 & \text { The Role of Models and Technology } & 88\end{array}$

\section{PART II TAKING ACTION}

Chapter 8 Strengthening Protected Areas $\quad 109$

$\begin{array}{lll}\text { Chapter } 9 & \text { Focusing on Species } & 123\end{array}$

$\begin{array}{ll}\text { Chapter } 10 \text { The Role of Connectivity } & 136\end{array}$

$\begin{array}{ll}\text { Chapter } 11 \text { Restoring for the Future } & 147\end{array}$

Chapter 12 The Hordes at the Gates: Beating Back Invasive Species, Pests, and Diseases

\section{PART III RETHINKING GOVERNANCE, POLICY,} AND REGULATION

Chapter 13 Regulating Harvest in a Changing World 171

$\begin{array}{ll}\text { Chapter } 14 \text { Regulating Pollutants in a Changing World } & 180\end{array}$ 
viii Contents

Chapter 15 Integrating the Needs of Nature and People 189

Chapter 16 Adapting Governance for Change 199

Afterword: Creative Thinking in Conservation and Management 213

$\begin{array}{ll}\text { References } & 220\end{array}$

About the Authors 233

$\begin{array}{ll}\text { Index } & 235\end{array}$ 
This book would never have seen the light of day had we not received the support and encouragement of a multitude of people.

The following individuals generously reviewed one or more chapters of the book: Tom Lovejoy, Hannah Reid, Hector Galbraith, John Matthews, Emma Tompkins, Earl Saxon, Erica Fleischman, Caroly Shumway, Anton Seimon, Marianne Fish, Gary Tabor, Lance Morgan, Marah Hardt, Robie MacDonald, Craig Segall, Jeb Byers, Joanna Ellison, Richard Hobbs, Dominique Bachelet, Katharine Hayhoe, Teresa A'mar, Diane Mcfadzien, Sandeep Rai, John Nordgren, Carl Bruch, Dan Schramm, and Cassandra Brooke. Their candid commentary improved the book greatly.

We thank Barbara Dean, Todd Baldwin, and Erin Johnson at Island Press for striking such a nice balance between encouragement and harassment, and Marce Rackstraw for being patient, expeditious, and responsive and for turning out such lovely graphics. We also wish to thank Carlos Drews, Nick Lunn, Dee Boersma, Wendy Foden, Mark Anderson, and Anton Seimon for letting us tell their stories, Bruce Stein for his wonderful sunburn analogy, Earl Saxon for collaboration on the creation of figure 3.2, and Chris Bergh for providing us with the Key deer maps for figure 8.1. Mar Wonham provided research help for chapter 12, Meade Krosby for chapter 10, and Tasha Belfiore for chapters 8 and 9. The Kresge Foundation provided the funding that gave us the time to write this book while still allowing us to pay our rent.

We are indebted to our friends, family, and coworkers who put up with us as we periodically turned into writing zombies. They kept the home fires burning (quite literally for JRH, since she and Daniel heat with wood), made sure that work got done, and were really quite pleasant about it all. Special thanks to Eric Mielbrecht for telling us this would take more time than we thought but not making too big a deal about it when it did.

We are also grateful to all the people we have interacted with over the years who have helped us to refine the ideas presented here. This includes everyone who attended a Climate Camp, talked to us on the phone, participated in a class we taught, or stopped us to talk in a hall outside a meeting.

This book would not have been possible without the great libraries in our lives: American University Jack and Dorothy G. Bender Library, the Seattle Public Library, Bainbridge Island Public Library of the Kitsap Regional Libraries, the University of California Library system, and the University of Washington Library system. We made every effort to reduce greenhouse gas emissions, so we would like to thank the good 
x Acknowledgments

public transit systems on which we rely (Washington State Ferry System, King and Kitsap County Metro Transit systems, Washington Metropolitan Transit Authority), our bicycles (Lara's Blue Mariah and Jennie's beloved Bridgestone that was, alas, stolen near the end of the book-writing process), and good shoes for walking (left and right).

Last but not least, we are very, very grateful to everyone who picks up this book and decides to include the reality of climate change in some decisions they make. 